\title{
Uncovering the Phytochemicals of Root Exudates and Extracts of Lead (Pb) Hyperaccumulator Vetiveria Zizanioides (L.) in Response to Lead Contamination and their Effect on the Chemotactic Behaviour of Rhizospheric Bacteria
}

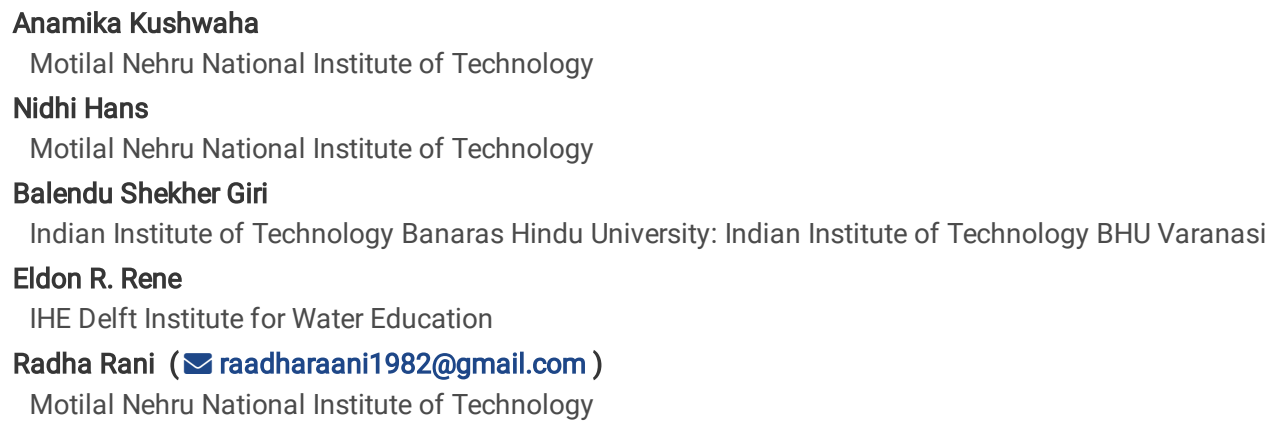




\section{Abstract}

Chemical composition of root exudates and root extracts from V. zizanioides cv KS-1 was determined, in the presence of lead [Pb(II)]. Hitherto, no information is available in the literature concerning the phytochemical components of root exudates of Vetiver zizanioides. Significantly higher concentrations of total carbohydrates ( 26.75 and $42.62 \%$ in root exudates and root extract, respectively), reducing sugars ( 21.46 and $56.11 \%$ in root exudates and root extract, respectively), total proteins ( 9.22 and $23.70 \%$ in root exudates and root extract, respectively), total phenolic acids ( 14.69 and $8.33 \%$ in root exudates and root extract, respectively), total flavonoids ( 14.30 and $12.28 \%$ in root exudates and root extract, respectively) and total alkaloids (12.48 and $7.96 \%$ in root exudates and root extract, respectively) were observed in samples from plants growing under $\mathrm{Pb}(\mathrm{II})$ stress in comparison to the respective controls. GC-MS profiling showed the presence of diverse group of compounds in root exudates and extracts including terpenes, alkaloids, flavonoids, carotenoids, plant hormones, carboxylic/organic acids and fatty acids. Among the detected compounds, many have important role in plant development, regulating rhizosphere microbiota, and allelopathy. Furthermore, the results indicated that $V$. zizanioides exudates possess a chemotactic response for rhizospheric bacterial strains Bacillus licheniformis, Bacillus subtilis and Acinetobacter junii $\mathrm{Pb} 1$.

\section{Introduction}

Rapid global industrialization and urbanization has caused severe soil contamination problems. Among them, pollution due to heavy metals (HM) has been a serious concern due to its toxic effects on human health and the ecosystem, including the flora and fauna (Arul et al. 2016; Bind et al. 2019). Among all HM contaminants, $\mathrm{Pb}$ is considered as one of the most toxic pollutant because it tends to (bio)accumulate at high rates in soil environments (Kushwaha et al. 2017, Singh et al. 2019; Sathe et al. 2020). The common anthropogenic sources of Pb contamination in the environment include smelting of ores, burning of coal, mining, effluents from battery industries, automobile exhausts, metal plating, leather tanning, finishing operations, and the overuse of fertilizers and pesticides (Goswami et al. 2017, Kushwaha et al. 2020). The bioavailability of HM in soil is a serious aspect which has to be monitored in order to restore a contaminated site. Thus, environment researchers have given it a serious concern, thereby, ensuring human health (Bind et al. 2018; Goswami et al. 2020).

In this line of progressive research, phytoremediation is a novel, cost-effective, efficient, environment friendly and solar-driven remediation technology, which has proven to improve the soil quality (Kushwaha et al. 2015). Vetiveria zizanioides cv KS-1 (VZ) was selected in this study due to its ability to grow in extreme environmental conditions and demonstrate high biomass yield within short time durations. A native of India, it is also known as the 'wonder grass' and it is extensively used in majority of the tropical countries for the phytoremediation of various contaminants present in water bodies. Since, it grows rapidly, it is more effective for the restoration of contaminated sites in only 4-5 months as compared with trees and shrubs which usually require 2-3 years (Sinha et al. 2009). Vetiveria zizanioides is known to tolerate high alkalinity and acidity (pH 3.0 to 10.5), salanity (EC $8 \mathrm{dSm}^{-1}$ ), high concentration of heavy metals (lead, mercury, copper, zinc, arsenic, cadmium, nickel, magnesium, manganese, aluminium and selenium), pesticides and herbicides. It has been reported that vetiver grass stabilized $\mathrm{Pb}(\mathrm{II})$ in root zone with moderate translocation) to above ground biomass (shoots). Thus, its shoots can be safely used as fodder or grazed by animals. Earlier literatures have reported the mechanisms involved in the accumulation and transportation of inorganic pollutants in $\mathrm{V}$. zizanioides, but still some mechanisms remain rather unclear, especially the role of root exudates (REs).

REs plays a significant role in phytoremediation. The high density and diversity of rhizopsheric microorganisms is due to the effect of various RE components. The secondary metabolites released from plant roots during stressful environmental conditions could improve the nutrient uptake and help the plant to cope with those stresses (Luo et al. 2015). The chemical constituent of REs, root extracts (Ret) and their concentration depends upon various factors such as the plant type, plant species, soil, environmental and geographical conditions, biotic and abiotic stress and collection method (Rani and Juwarkar 2016; Dutta et al. 2019). REs is mainly classified into two types, i.e. low molecular weight (LMW) and high molecular weight (HMW) compounds. LMW REs is typically composed of organic acids, sugars, phenols and various amino acid and non-proteinaceous amino acids (phytosiderophore), while HMW is majorly composed of mucilage and proteins. Root secretions are known to stimulate the solubility and mobility of HM ions in soil thereby enhancing the phytoextraction efficiency of the plant (Rajkumar et al. 2012). Organic acids (citric and oxalic acid) released by the roots of Echinochloa crusgalli have been reported to increase the $\mathrm{Cu}(\mathrm{II}), \mathrm{Cd}(\mathrm{II})$ and $\mathrm{Pb}(\mathrm{II})$ translocation from below ground biomass to above ground biomass (Kim et al. 2010).

To the best of the authors knowledge, this is the first report that describes the exudation behaviour of VZ in presence of $\mathrm{Pb}$ (II) and its role as chemoattractant. Besides, very little data are available in the literatures concerning the effect of different level $\mathrm{Pb}(\mathrm{II})$ on the phytocomponents of vetiver grass and its chemotactic effects. Therefore, the present study will help to envisage the role of various phytocomponents of vetiver grass on the $\mathrm{Pb}$ (II) tolerance capacity. Thus, the specific objectives of this work can be stated as follows: (i) to perform chemical characterization of the REs and REt from the Pb hyperaccumulator VZ, and (ii) to determine the chemotaxis response of rhizospheric bacteria (Bacillus licheniformis, Bacillus subtilis and A. junii Pb1) towards VZ exudates.

\section{Materials And Methods}

\subsection{Materials}

Analytical grade chemicals were used in this study. Lead nitrate $\left[\mathrm{Pb}\left(\mathrm{NO}_{3}\right)_{2}\right]$ (Merck, India) was used for preparing the stock solution of $\mathrm{Pb}(\mathrm{II})$. The respective concentrations of the working solution were made from the stock solution using deionised water $(18 \Omega)$. The plant slips of VZ were purchased from the Central Institute of Medicinal and Aromatic Plants, Lucknow (Uttar Pradesh, India). All experiments were performed in triplicates.

\subsection{Collection of root exudates and root extracts}

REs from VZ were obtained by the sand culture method described by Gaidamak (1971) and REt were collected by extracting the roots in calcium chloride solution described by Liebersbach et al. (2004). Briefly stating, for REs, the roots of VZ was washed with tap water followed by distilled water. Hoagland solution was sprinkled periodically in order to maintain $30-40 \%$ of the water holding capacity of sand and for the growth of plant. To study the variance in the 
exudation behaviour of plant in the presence of $\mathrm{Pb}(\mathrm{II})$, one set of experiment was spiked with $\mathrm{Pb}(\mathrm{II})\left(100 \mathrm{mg} \mathrm{kg}^{-1}\right)$, while the other was used as the control (non-spiked). For the collection of REs, the top excess portion of Hoagland solution was withdrawn so that the Hoagland solution along with root washings overflows and gets collected in the beaker at the bottom of the experimental setup. In this manner, REs was collected on the 20th and 60th day.

REt were collected according to the $\mathrm{CaCl}_{2}$ extraction method described by Liebersbach et al. (2004). Experiments for two treatments were performed, i.e. one spiked with $\mathrm{Pb}(\mathrm{II})$ (experimental), while the other served as the control (non-spiked). For the collection of REt, the plants were uprooted and placed in freshly prepared $0.5 \mathrm{mM} \mathrm{CaCl}_{2}$ solution for $2 \mathrm{~h}$. Thus, the REt were collected on the 20th and 60 th day. After collecting the samples, the REs and REt were sterilized by passing through $0.22 \mu \mathrm{m}$ membrane filter, purified by dialysis, concentrated 15 -fold by lyophilisation, and stored at $-4^{\circ} \mathrm{C}$ until further analysis.

\subsection{Chemical characterization of root exudates and root extracts}

REs and REt were analysed for total carbohydrate content using the Anthrone's method (Hedge and Hofreiter, 1962), reducing sugars concentration by the Dintrosalicylic Acid (DNS) (Miller 1959), proteins by performing the Bradford's test (Bradford, 1976), total phenolic acid content by performing Folin-Ciocalteu assay tests (Kaur et al. 2002), total flavonoid content using aluminium chloride (Chang et al. 2002) and total alkaloids by the acid dye method (Tambe and Bhambar 2014).

\subsection{GC-MS detection of root exudates}

REs and REt of VZ was further analysed by gas chromatography-mass spectrometry GS-MS (Thermo Scientific TSQ 8000). The MS part consisted of Triple Quadrupole and it was paired with the TRACE $1300 \mathrm{GC}$, fitted with an auto-sampler. REs (control and $100 \mathrm{mg} \mathrm{kg}^{-1}$ ) and REt (control and $100 \mathrm{mg} \mathrm{kg}{ }^{-1}$ ) were lyophilized 20 times and suspended in acetone and subsequently subjected to GC-MS analysis. Chromatographic separation was achieved under the following conditions: injection temperature $240^{\circ} \mathrm{C}, 3 \mathrm{~min} @ 80^{\circ} \mathrm{C}$ isothermal followed by a ramp of $5^{\circ} \mathrm{C} \mathrm{min}{ }^{-1}$ to $320^{\circ} \mathrm{C}$ for $5 \mathrm{~min}$ and gas flow rate $2 \mathrm{~mL}$ min

1 . Mass spectra were recorded at 10 spectra $\mathrm{sec}^{-1}$ with an $\mathrm{m} / \mathrm{z}$ scanning range of 50 to 700 . The compounds were identified by comparing the mass spectra from the NIST library database.

\subsection{Chemotactic effect of root exudates on rhizospheric microorganisms}

The chemotactic effect of REs on rhizospheric microorganisms was assessed by the agar diffusion method. The minimal media was prepared with $0.75 \%$ agar powder in petri plates. The $14 \mathrm{~h}$ old culture having an optical density (OD) of 1.0 contained different bacterial strains, Bacillus subtilis, Bacillus licheniformis and the lead resistant bacterium Acinetobacter junii Pb1 were used for performing chemotactic studies. Two wells were created in petri plates and $80 \mu \mathrm{l}$ of root exudates was added in one, while distilled water was added to the other well that acted as the control. At the centre of the petridish, equidistant from both the wells, $5 \mu$ of culture (OD: 1.0) was inoculated and incubated for $12 \mathrm{~h}$ at $30^{\circ} \mathrm{C}$. The chemotactic effect of REs towards the different bacterial strains was observed after $12 \mathrm{~h}$ of incubation.

\subsection{Statistical analysis}

All the experiments were carried out in triplicates. The experimental data were statistically analysed and presented with the appropriate standard deviation values. The data was also subjected to Student's t-test using the RAUSTAT software (Dr. R.C. Bharti, PUSA). $P<0.05$ were considered to be statistically significant. The data analysis and preparation of graphs were done using the GraphPad Prism 5software.

\section{Results And Discussion}

\subsection{Chemical characterisation of root exudates and extract of VZ}

\subsubsection{Total carbohydrates content}

The concentration of total carbohydrates in REs and REt on the 20 and 60th day of plant growth are given in Table 1. It can be seen that, there was insignificant change $(P>0.05)$ in the carbohydrate content of both REs and REt on the 20th day between the control and test samples (Fig. 1). However, a significant difference $(P<0.05)$ was observed in the carbohydrate content in both REs and REt on the 60th day (Fig. 1). On the 60th day, the total carbohydrate content increased by 26.75 and $42.67 \%$ in the REs and REt, respectively, in the presence of $\mathrm{Pb}$ (II) when compared to control (Table 2 ). The carbohydrate content varied significantly in REs and REt on the 60th day, wherein the highest carbohydrate concentration was observed in REt as compared to REs (Table 2). The difference in carbohydrate content suggest that the concentration of the same component differ depending upon the technique used for its collection. Rani and Juwarkar $(2015 ; 2016)$ reported that the chemical composition of both REs and REt depends not only on the plant species, soil, environmental and geographical surroundings, but also on the technique used for its collection. In a previous work, Krishnaraj et al. (2012) studied the effect of biologically synthesized silver nanoparticles (AgNPs) on Bacopa monnieri (Linn.) Wettst. and reported an increase in the carbohydrate content in AgNPs treated plant when compared to the control. The carbohydrate content of REs mainly includes mucilaginous substances (HMW) secreted by the root tissues; however, it also includes a minor portion of sugars (LMW). These carbohydrates act as the carbon source for microorganisms and alter the activity and number of microorganisms, thereby affecting the HM bioavailability in soil. 
Table 1

Characterization of root exudates and root extracts in the presence and absence of $\mathrm{Pb}$ (II)

\begin{tabular}{|c|c|c|c|c|c|}
\hline \multirow[t]{2}{*}{ Component } & & \multicolumn{2}{|c|}{$\begin{array}{l}\text { Concentration of root } \\
\text { exudates }\end{array}$} & \multicolumn{2}{|c|}{$\begin{array}{l}\text { Concentration of root } \\
\text { extract }\end{array}$} \\
\hline & & 20th day & 60th day & 20th day & 60th day \\
\hline \multirow{2}{*}{$\begin{array}{l}\text { Total } \\
\text { carbohydrate } \\
\left(\mu \mathrm{g} \mathrm{ml}^{-1}\right)\end{array}$} & Control & $0.404 \pm 0.021$ & $0.459 \pm 0.0407$ & $0.413 \pm 0.0282$ & $0.456 \pm 0.0497$ \\
\hline & Test & $0.438 \pm 0.049$ & $0.626 \pm 0.044$ & $0.422 \pm 0.0502$ & $0.651 \pm 0.0498$ \\
\hline \multirow[t]{2}{*}{ Reducing sugar $\left(\mu \mathrm{g} \mathrm{ml}^{-1}\right)$} & Control & $0.366 \pm 0.012$ & $0.419 \pm 0.004$ & $0.392 \pm 0.017$ & $0.377 \pm 0.017$ \\
\hline & Test & $0.399 \pm 0.008$ & $0.509 \pm 0.009$ & $0.451 \pm 0.013$ & $0.530 \pm 0.031$ \\
\hline \multirow[t]{2}{*}{ Total Protein $\left(\mu \mathrm{g} \mathrm{ml}^{-1}\right)$} & Control & $1.683 \pm 0.125$ & $1.982 \pm 0.074$ & $1.806 \pm 0.099$ & $1.992 \pm 0.067$ \\
\hline & Test & $1.928 \pm 0.104$ & $2.165 \pm 0.149$ & $2.130 \pm 0.200$ & $2.464 \pm 0.253$ \\
\hline \multirow{2}{*}{$\begin{array}{l}\text { Total Phenolic } \\
\left(\mu \mathrm{g} \mathrm{ml}^{-1}\right)\end{array}$} & Control & $54.92 \pm 2.5$ & $56.27 \pm 2.57$ & $57.74 \pm 1.96$ & $73.74 \pm 2.1$ \\
\hline & Test & $60.385 \pm 2.965$ & $64.535 \pm 2.965$ & $54.999 \pm 1.929$ & $79.888 \pm 2.468$ \\
\hline \multirow{2}{*}{$\begin{array}{l}\text { Total Flavonoids } \\
\left(\mu \mathrm{g} \mathrm{ml}^{-1}\right)\end{array}$} & Control & $155.727 \pm 5.364$ & $162.090 \pm 5.818$ & $169.636 \pm 4.000$ & $173.999 \pm 3.454$ \\
\hline & Test & $161.136 \pm 7.409$ & $185.272 \pm 4.818$ & $177.272 \pm 4.727$ & $195.363 \pm 10.454$ \\
\hline \multirow{2}{*}{$\begin{array}{l}\text { Total Alkaloids } \\
\left(\mu \mathrm{gl}^{-1}\right)\end{array}$} & Control & $7.579 \pm 0.301$ & $8.05 \pm 0.25$ & $7.939 \pm 0.301$ & $9.638 \pm 0.302$ \\
\hline & Test & $8.237 \pm 0.335$ & $9.055 \pm 0.445$ & $8.584 \pm 0.296$ & $10.405 \pm 0.495$ \\
\hline
\end{tabular}

Table 2

Change in the root exudate and extract profiles (in \%) on the 60th day

\begin{tabular}{|llc|}
\hline Component & Percent change in root exudates on lead exposure & Percent change in root extract on lead exposure \\
\hline Total carbohydrate $\left(\mu \mathrm{g} \mathrm{ml}^{-1}\right)$ & $+26.75^{*}$ & $+42.62^{*}$ \\
\hline Reducing sugar $\left(\mu \mathrm{g} \mathrm{ml}^{-1}\right)$ & $+21.46^{*}$ & $+56.11^{*}$ \\
\hline Total Protein $\left(\mu \mathrm{g} \mathrm{ml}^{-1}\right)$ & $+9.22^{*}$ & $+23.70^{\star}$ \\
\hline Total Phenolic $\left(\mu \mathrm{g} \mathrm{ml}^{-1}\right)$ & $+14.69^{*}$ & $+8.33^{*}$ \\
\hline Total Flavonoids $\left(\mu \mathrm{g} \mathrm{ml}^{-1}\right)$ & $+14.30^{*}$ & $+12.28^{*}$ \\
\hline Total Alkaloids $\left(\mu \mathrm{g} \mathrm{ml}^{-1}\right)$ & $+12.48^{*}$ & $+7.96^{*}$ \\
\hline
\end{tabular}

\subsubsection{Reducing sugars content}

Reducing sugars in REs and REt on the 20 and 60th day of plant age is given in Table 1. On the 20th day, insignificant difference $(P>0.05)$ was observed in the total reducing sugar concentrations of REs and REt, between the control and test samples (Fig. 2). However, on the 60th day, the total reducing sugar concentration increased by $21.46 \%$ and $56.11 \%$ in REs and REt, respectively $(P<0.05)$ in the presence of $\mathrm{Pb}(\mathrm{II})$ (Table 2$)$. Increase in the reducing sugar content in plants, upon expose to $\mathrm{HM}$ has been reported recently (Shah et al. (2017). The authors observed an increase in the reducing sugar content by $47.95 \%$ in Tagetes erecta $\mathrm{L}$. when grown in cadmium $\left(18 \mathrm{mg} \mathrm{kg}^{-1}\right)$ treated soil, while a further increase in the cadmium levels decreased the reducing sugar content significantly.

\subsubsection{Total protein content}

Total protein in REs and REt on the 20th and 60th day of plant age is given in Table 1. As observed previously for the carbohydrates and reducing sugar contents, on the 20th day, insignificant change $(P>0.05)$ was observed in the protein content for REs and REt between the control and test samples (Fig. 3 ). However, in the case of REt, a significant difference $(P<0.05)$ was observed in the protein content on the 60th day (Fig. 3). The protein concentration was found to increase by 9.22 and $23.70 \%$ in REs and REt, respectively $(P<0.05)$ in presence of $\mathrm{Pb}(\mathrm{II})(\mathrm{Table} 2)$. Thus, the protein content in both REs and REt was found to increase in presence of lead when compared to the control experiments. Gohari et al. (2012) reported an increase in the protein content in roots of two varieties (Hyola308 and RGS003) of Brassica napus L. with an increase in $\mathrm{Pb}(\mathrm{II})$ concentration (0 to $400 \mu \mathrm{M}$ ). Increase in protein secretion from plant roots in the presence of $\mathrm{Pb}(\mathrm{II})$ implies significant biological functions, enzymatic changes, and alteration in the defence mechanisms related to the uptake and transformation of lead compounds.

\subsubsection{Total phenolic acids content}

The total phenolic acids concentration in REs and REt are presented in Table 1. As shown in Fig. 4, no significant difference (P>0.05) in the phenolic acids content was observed in REs and REt between the control and test samples on the 20th day. However, on the 60th day, a significant increase $(P<0.05)$, in REs 
and REt, i.e. $14.69 \%$ and $8.33 \%$, respectively, in the phenolic acids content was observed in the presence of Pb(II). It is noteworthy to mention that, increased secretion of phenolic acids from roots under heavy metal stress have been reported in several previous studies. For example, Irtelli and Navari-Izzo (2006) reported that in the presence of $\mathrm{Cd}(\mathrm{II})\left(150 \mathrm{mg} \mathrm{kg}^{-1}\right)$ an increase in phenolic acids content was noticed in Brassica juncea. Jung et al. (2003) also reported an increase in the phenolic acids content (particularly genistein and genistein-(malonyl)-glucoside) in the roots of Lupinus albus $\mathrm{L}$. when exposed to $20 \mu \mathrm{M}$ copper solution. Márquez-García et al. (2012) reported an increase in the total phenolic content in Erica andevalensis when treated with Cd(II) (5 $\mu \mathrm{g} \mathrm{g}^{-1}$ soil).

Phenolic acids present in REs and REt are usually linked with numerous functions. They have redox properties, which act as antioxidants. The presence of hydroxyl groups is known to be responsible for scavenging the free radicals generated during periods of unexpected environmental stress. Thus, the total phenolic acids concentration could be used to access the antioxidant activity (Baba and Malik 2015). The antioxidant activity of phenolic compounds is mainly due to their reduced properties which allow them to act as metal chelators, absorb and neutralize the free radicals. They also act as growth promoters and chemoattractant for microorganisms present in soil. Many phenolic compounds act as defence mechanism in plants against pathogens, have allelophatic activity and act as phytoalexins (Rani and Juwarkar 2016).

\subsubsection{Total flavonoid content}

The results of total flavonoid content in REs and REt are presented in Table 1. On the 60th day, an increase by $14.30 \%$ and $12.28 \%$ in the flavonoid content of REs and REt, respectively, with $\mathrm{P}<0.05$, was observed in the presence of $\mathrm{Pb}$ (II) (Fig. 5). In a previous study, Parry et al. (1994) reported the increase in isoflavonoid content in roots of Alfalfa when treated with $1 \mathrm{mM} \mathrm{CuCl}_{2}$. Tumova and Ruskova (1998) reported an increase in the flavonoid content in callus culture of Ononis arvensis when $\mathrm{CuSO}_{4}$ and $\mathrm{CdCl}_{2}$ concentrations were increased. Flavonoids, flavones, condensed tannins and flavanols are secondary metabolites present in plant. Flavonoids are known to act as the scavengers of free radicals generated under oxidative stress. Due to the presence of the free hydroxyl groups, especially $3-\mathrm{OH}$, flavonoids exhibits antioxidant activity. Besides radical scavengers, flavonoids can also act as metal chelators depending on the molecular structure (Kumar and Pandey 2013). In addition, anthocyanins which are synthesized through the same pathway as that of flavonoids, are known to be tolerant towards metals.

\subsubsection{Total alkaloids content}

The total alkaloid content of REs and REt are given in Table 1. Similar to prior observations, on the 20th day, insignificant change $(P>0.05)$ was observed in the content of alkaloids in REs and REt between control and test samples (Fig. 6). Conversely, in the presence of Pb(II), on the 60th day, the alkaloid concentrations increased by $12.48 \%$ and $7.96 \%$ in REs and REt, respectively $(P<0.05)$ (Table 2). Srivastava and Srivastava (2010) reported that when Catharanthus roseus $\mathrm{L}$. was exposed to $5 \mathrm{mM}$ of $\mathrm{Mn}, \mathrm{Ni}$, and $\mathrm{Pb}$, the alkaloid contents increased significantly in the roots. ArefiFard (2017) also reported an increase in the alkaloid content in shoots and roots of Catharanthus roseus when exposed to $\mathrm{NiCl}_{2}$. It is well-known that, under harsh environmental conditions or environmental stress, an alteration in metabolic activity towards protective secondary metabolites can be expected to occur as a mode of strengthening the defence mechanism. The increase in alkaloid content is presumably due to the increase in endogenous methyl jasmonate which is involved in catalysing the enzymes responsible for alkaloid biosynthesis (Turner et al. 2002). Thus, the accumulated alkaloids are known to be responsible for inducing the defence mechanism in plants. The results from this study showed that, REs and REt of $V$. zizanioides comprises of varied chemical components including carbohydrates, proteins, alkaloids, flavonoids and phenolic.

\subsection{GC-MS analysis of root exudates}

The results from GC-MS analysis led to the identification of a number of compounds from the GC fractions of REs and REt. The compounds identified in REs and REt in absence and presence of $\mathrm{Pb}(\mathrm{II})$ through mass spectrometry are shown in Figs S1 and S2, respectively, and Tables 3 to 6 with their retention time (RT), molecular formula and their functions. Figure 7 and Tables 5 and 6 provides the detailed list of compounds identified in the extract, i.e. in the absence and presence of $\mathrm{Pb}(\mathrm{II})$. In presence of $\mathrm{Pb}$ (II) various phyto-compounds such as 1-Phenanthrenecarboxylic acid; tetradecahydro-7-(2-methoxy-2-

oxoethylidene)-1,4a,8-trimethy - 9-oxo,methylester; hexatbutylselenatrisiletane; 1,3-cyclohexadiene,1-methyl-4-(1-methyl ethyl); cyclohexene-1-methyl-4-(1methylethylidene); 2,4,6-octatriene, 2,6dimethyl-; (+)-4-carene; benzene-1-methyl-3-(1-methylethyl); ç-terpinene; 9,12,15-octadecatrienoicacid, 2,3bis[(trimethylsilyl)oxy]polylester are known to have antioxidant properties and act as a defence response against insect attack and fungal pathogen infection. Among the identified compounds some are reported to be potential therapeutic agents. They inherently possess antimicrobial, antioxidant, anti-inflammatory, insecticide, and antifungal characteristics. Huang et al. (2010) also reported the presence of 9,12,15-octadecatrienoicacid,2,3-bis [(trimethylsilyl)oxy]polylester and 1-Phenanthrenecarboxylic acid in REs of cowpea. The presence of 9,12,15-octadecatrienoicacid,2,3-bis[(trimethylsilyl)oxy]polylester has been reported in Cyperus alternifolius REs when exposed to a mixture of $\mathrm{HM}$ (Cd, Cu, Cr, Ni, Zn, $\mathrm{Pb}$, and $\mathrm{Fe}$ ) (Usharani and Vasudevan 2017). 
Table 3

Chemical composition of the root exudates (control)

\begin{tabular}{|c|c|c|c|c|c|}
\hline $\begin{array}{l}\text { Sl. } \\
\text { No. }\end{array}$ & $\begin{array}{l}\mathrm{RT} \\
(\min .)\end{array}$ & $\begin{array}{l}\text { Area } \\
\%\end{array}$ & Compound name and Molecular formula & Function and Class & References \\
\hline 1 & 6.58 & 29.19 & $2,4,6$ Octatriene, 2,6 dimethyl $\left(\mathrm{C}_{10} \mathrm{H}_{16}\right)$ & Organic compounds, pleasant odor & Kishimoto et al. 2005 \\
\hline 2 & 6.58 & 29.19 & (+)4Carene $\left(\mathrm{C}_{10} \mathrm{H}_{16}\right)$ & Antimicrobial activity, monoterpenes, hydrocarbons & $\begin{array}{l}\text { Omoruyi and } \\
\text { Muchenje (2017) }\end{array}$ \\
\hline 3 & 6.58 & 29.19 & $\begin{array}{l}\text { 1,3Cyclohexadiene, } 1 \text { methyl4(1 methylethyl) } \\
\left(\mathrm{C}_{10} \mathrm{H}_{16}\right)\end{array}$ & Alpha terpinene, isomeric hydrocarbons & $\begin{array}{l}\text { Najafian and } \\
\text { Zahedifar (2015) }\end{array}$ \\
\hline 4 & 6.73 & 16.90 & Benzene, 1ethyl2,4dimethyl $\left(\mathrm{C}_{10} \mathrm{H}_{14}\right)$ & Organic compound, insecticide & Runde et al. (2015) \\
\hline 5 & 6.73 & 16.90 & Benzene, 1 methyl $3\left(1\right.$ methylethyl) $\left(\mathrm{C}_{10} \mathrm{H}_{14}\right)$ & Aromatic organic compound, alkyl benzene & Tang et al. (2003) \\
\hline 6 & 6.73 & 16.90 & Benzene, 1,2,4,5tetramethyl $\left(\mathrm{C}_{10} \mathrm{H}_{14}\right)$ & Organic compound, antioxidant activity under Al stress & Wang et al. (2006) \\
\hline 7 & 6.82 & 4.59 & $\begin{array}{l}\text { Cyclohexene, } 1 \text { methyl5(1 methylethenyl),(R) } \\
\left(\mathrm{C}_{10} \mathrm{H}_{16}\right)\end{array}$ & Antimicrobial activity, hydrocarbon compound & $\begin{array}{l}\text { Mohammed et al. } \\
(2016)\end{array}$ \\
\hline 8 & 6.82 & 4.59 & Limonene $\left(\mathrm{C}_{10} \mathrm{H}_{16}\right)$ & $\begin{array}{l}\text { Monoterpene, found in citrus fruits, induces shifts in } \\
\text { bacterial } \\
\text { community composition }\end{array}$ & $\begin{array}{l}\text { Musilova et al. } \\
\text { (2016); Jha et al. } \\
\text { (2015) }\end{array}$ \\
\hline 9 & 6.89 & 3.92 & Eucalyptol $\left(\mathrm{C}_{10} \mathrm{H}_{18} \mathrm{O}\right)$ & $\begin{array}{l}\text { Organic compound, antifungal, insect repellent and } \\
\text { insecticide }\end{array}$ & $\begin{array}{l}\text { Tripathi et al. (2016), } \\
\text { Tayade et al. (2013) }\end{array}$ \\
\hline 10 & 6.89 & 3.92 & Trifluoroacetylàterpineol $\left(\mathrm{C}_{12} \mathrm{H}_{17} \mathrm{~F}_{3} \mathrm{O}_{2}\right)$ & $\begin{array}{l}\text { Monoterpene alcohol, antioxidant, anticancer, } \\
\text { anticonvulsant, antiulcer, antihypertensive, anti- } \\
\text { nociceptive }\end{array}$ & Khaleel et al. (2018) \\
\hline 11 & 7.44 & 40.59 & çTerpinene $\left(\mathrm{C}_{10} \mathrm{H}_{16}\right)$ & Monoterpene, antimicrobial activity & $\operatorname{Lim}(2016)$ \\
\hline 13 & 8.10 & 3.94 & 2,4,6 Octatriene,2,6-dimethyl $\left(\mathrm{C}_{10} \mathrm{H}_{16}\right)$ & $\begin{array}{l}\text { Volatile organic compound, resistant against the fungal } \\
\text { disease, ethylene and } \\
\text { jasmonic acid signalling pathways }\end{array}$ & $\begin{array}{l}\text { Kishimoto et al. } \\
\text { (2005); Kishimoto et } \\
\text { al. (2006); Silva et al. } \\
\text { (2013) }\end{array}$ \\
\hline 14 & 50.20 & 0.87 & $\begin{array}{l}\text { Propanoic acid, 2-(3-acetoxy-4,4,14- } \\
\text { trimethylandrost-8-en-17-yl) }\left(\mathrm{C}_{27} \mathrm{H}_{42} \mathrm{O}_{4}\right)\end{array}$ & Carboxylic acid, antimicrobial, antitumor, insecticidal & Kadhim et al. (2016) \\
\hline 15 & 50.20 & 0.87 & $\begin{array}{l}\text { 9,12,150ctadecatrienoicacid, } \\
2,3 \text { bis[(trimethylsilyl)oxy]propylester, } \\
(\mathrm{Z}, \mathrm{Z}, \mathrm{Z})\left(\mathrm{C}_{27} \mathrm{H}_{52} \mathrm{O}_{4} \mathrm{Si}_{2}\right)\end{array}$ & $\begin{array}{l}\text { Flavonoids, anti-inflammatory, antioxidant, } \\
\text { hypocholesterolemic, cancer preventive, hepatoprotective, } \\
\text { antiarthritic, antihistimic, antieczemic and anticoronary } \\
\text { activity }\end{array}$ & $\begin{array}{l}\text { Rajendran et al. } \\
\text { (2017) }\end{array}$ \\
\hline
\end{tabular}


Table 4

Chemical composition of the root exudates at $100 \mathrm{mg} \mathrm{kg}^{-1}$

\begin{tabular}{|c|c|c|c|c|c|}
\hline $\begin{array}{l}\text { Sl. } \\
\text { No. }\end{array}$ & $\begin{array}{l}\mathrm{RT} \\
\text { (min.) }\end{array}$ & $\begin{array}{l}\text { Area } \\
\%\end{array}$ & $\begin{array}{l}\text { Compound name and Molecular } \\
\text { formula }\end{array}$ & Function and Class & References \\
\hline 1 & 5.51 & 3.46 & $\begin{array}{l}\text { 1-Phenanthrenecarboxylic acid, } \\
\text { tetradecahydro-7-( } \\
\text { 2-methoxy-2-oxoethylidene)- } \\
\text { 1,4a, 8-trimethyl-9-oxo-, } \\
\text { methyl ester, } \\
\text { [1S }(1 \text { à,4aà,4bá,8á,8aà,10aá)- } \\
\left(\mathrm{C}_{22} \mathrm{H}_{32} \mathrm{O}_{5}\right)\end{array}$ & $\begin{array}{l}\text { Antioxidant activity under stress conditions, it } \\
\text { also has defense response against insect attack } \\
\text { and fungal pathogen infection. }\end{array}$ & Ning-Nan et al. (2007) \\
\hline 2 & 6.02 & 7.10 & $\begin{array}{l}\text { 9,12,150ctadecatrienoic acid, } \\
\text { 2,3bis[trimethylsilyl) oxy]propyl } \\
\text { ester, }(\mathrm{Z}, \mathrm{Z}, \mathrm{Z})\left(\mathrm{C}_{27} \mathrm{H}_{52} \mathrm{O}_{4} \mathrm{Si}_{2}\right)\end{array}$ & $\begin{array}{l}\text { Flavonoids. antimicrobial, anti-inflammatory, } \\
\text { hypocholesterolemic, cancer preventive, } \\
\text { hepatoprotective, antiarthritic, antihistimic, } \\
\text { antieczemic and anticoronary }\end{array}$ & Rajendran et al. (2017) \\
\hline 3 & 6.41 & 6.24 & $\begin{array}{l}\text { Hexa-t-butylselenatrisiletane } \\
\left(\mathrm{C}_{24} \mathrm{H}_{54} \mathrm{SeSi}_{3}\right)\end{array}$ & $\begin{array}{l}\text { Antioxidant activity, Antimicrobial, antitumor, } \\
\text { antiseptic, preservative, insecticidal }\end{array}$ & Abdul-Hafeez et al. (2015) \\
\hline 4 & 6.41 & 6.24 & Heptadecane, 9-hexyl $\left(\mathrm{C}_{23} \mathrm{H}_{48}\right)$ & Antifungal, pharmacological properties & $\begin{array}{l}\text { Abubacker and Devi (2015); Tayade et al. } \\
\text { (2013) }\end{array}$ \\
\hline 5 & 6.41 & 6.24 & $\begin{array}{l}\text { Octadecane, 3-ethyl-5-(2- } \\
\text { ethylbutyl) }\left(\mathrm{C}_{26} \mathrm{H}_{54}\right)\end{array}$ & $\begin{array}{l}\text { Antifungal activity, anti-inflammatory, } \\
\text { antioxidant }\end{array}$ & Morah et al. (2017) \\
\hline 6 & 6.57 & 28.90 & $\begin{array}{l}\text { 1,3-Cyclohexadiene,1-methyl-4- } \\
\text { (1-methylethyl) }\left(\mathrm{C}_{10} \mathrm{H}_{16}\right)\end{array}$ & $\begin{array}{l}\text { Y-Terpinene, Antioxidant, Antibacterial, } \\
\text { allelopathic, herbivore deterrent activity }\end{array}$ & $\begin{array}{l}\text { Radmanesh et al. (2015); Raj et al. } \\
\text { (2014); Jiménez-Osornio et al. (1996) }\end{array}$ \\
\hline 7 & 6.57 & 28.90 & $\begin{array}{l}\text { Cyclohexene, 1-methyl-4-(1- } \\
\text { methylethylidene) }\left(\mathrm{C}_{10} \mathrm{H}_{16}\right)\end{array}$ & Terpinolene, Antioxidant activity & Ruberto et al. (2000) \\
\hline \multirow[t]{2}{*}{8} & 6.57 & 28.90 & (+)4-Carene $\left(\mathrm{C}_{10} \mathrm{H}_{16}\right)$ & Monoterpene, insecticide, antimicrobial activity & $\begin{array}{l}\text { Mneimne et al. (2016); Bautista-Lozada } \\
\text { et al. (2013) }\end{array}$ \\
\hline & & & & & Smeriglio et al. (2017) \\
\hline 9 & 6.72 & 20.19 & $\begin{array}{l}\text { Benzene, 1-ethyl-2,4-dimethyl } \\
\left(\mathrm{C}_{10} \mathrm{H}_{14}\right)\end{array}$ & Antimicrobial, Insecticide & Choi et al. (2008) \\
\hline 10 & 6.72 & 20.19 & $\begin{array}{l}\text { Benzene, 1,2,4,5-tetramethyl } \\
\left(\mathrm{C}_{10} \mathrm{H}_{14}\right)\end{array}$ & $\begin{array}{l}\text { Aromatic compound, resistance against } \mathrm{Al}^{+3}, \\
\text { provide protection against insects and other } \\
\text { herbivores }\end{array}$ & Wang et al. (2006) \\
\hline 11 & 6.72 & 20.19 & $\begin{array}{l}\text { Benzene, 4-ethyl-1,2-dimethyl } \\
\left(\mathrm{C}_{10} \mathrm{H}_{14}\right)\end{array}$ & Aromatic compounds & http://foodb.ca/compounds/FDB007614 \\
\hline 12 & 6.81 & 6.12 & $\begin{array}{l}\text { Docosahexaenoic acid, } 1,2,3- \\
\text { propanetriylester }\left(\mathrm{C}_{69} \mathrm{H}_{98} \mathrm{O}_{6}\right)\end{array}$ & Phytochemical compound & Srivastava et al. (2015) \\
\hline 13 & 7.42 & 27.99 & çTerpinene $\left(\mathrm{C}_{10} \mathrm{H}_{16}\right)$ & Antimicrobial activity, Monoterpenoid & $\operatorname{Lim}(2016)$ \\
\hline 14 & 7.42 & 27.99 & 3-Carene $\left(\mathrm{C}_{10} \mathrm{H}_{16}\right)$ & Terpenoids, resist attack from pathogens & $\begin{array}{l}\text { Keeling and Bohlmann (2006); Arora } \\
\text { (1991) }\end{array}$ \\
\hline
\end{tabular}


Table 5

Chemical composition of the root extract (control)

\begin{tabular}{|c|c|c|c|c|c|}
\hline $\begin{array}{l}\text { Sl. } \\
\text { No. }\end{array}$ & $\begin{array}{l}\text { RT } \\
(\min .)\end{array}$ & $\begin{array}{l}\text { Area } \\
\%\end{array}$ & Compound name and Molecular formula & Function and Class & References \\
\hline 1 & 6.05 & 4.33 & 17-Pentatriacontene $\left(\mathrm{C}_{35} \mathrm{H}_{70}\right)$ & $\begin{array}{l}\text { Found in plant } \\
\text { extracts }\end{array}$ & Tayade et al., 2013 \\
\hline 2 & 6.05 & 4.33 & Oleic acid, eicosyl ester $\left(\mathrm{C}_{38} \mathrm{H}_{74} \mathrm{O}_{2}\right)$ & $\begin{array}{l}\text { Resistance against } \\
\text { pathogen, } \\
\text { antibacterial, anti- } \\
\text { inflammatory, cancer } \\
\text { preventive, } \\
\text { dermatitigenic } \\
\text { Hypocholesterolemic } \\
\text { and anemiagenic } \\
\text { Insectifuge }\end{array}$ & Upchurch (2008); Dilika et al. (20 \\
\hline 5 & 15.11 & 17.52 & Fluprednisolone $\left(\mathrm{C}_{21} \mathrm{H}_{27} \mathrm{FO}_{5}\right)$ & $\begin{array}{l}\text { Anti-inflammatory } \\
\text { agent }\end{array}$ & https://pubchem.ncbi.nlm.nih.go \\
\hline 6 & 15.11 & 17.52 & $\begin{array}{l}\text { 3Methoxymethoxy3,7,16,20tetramethylheneicosa } 1,7,11,15,19 \text { pentaene } \\
\left(\mathrm{C}_{27} \mathrm{H}_{46} \mathrm{O}_{2}\right)\end{array}$ & $\begin{array}{l}\text { Found in plant } \\
\text { extracts }\end{array}$ & Jisha et al., 2016 \\
\hline 7 & 16.94 & 14.32 & $\begin{array}{l}\text { 9,12,15-Octadecatrienoicacid, 2,3-bis [(trimethylsilyl)oxy]propyl ester, } \\
(\mathrm{Z}, \mathrm{Z}, \mathrm{Z})\left(\mathrm{C}_{27} \mathrm{H}_{52} \mathrm{O}_{4} \mathrm{Si}_{2}\right)\end{array}$ & $\begin{array}{l}\text { Flavonoids. } \\
\text { antimicrobial, anti- } \\
\text { inflammatory, } \\
\text { hypocholesterolemic, } \\
\text { cancer preventive, } \\
\text { hepatoprotective, } \\
\text { antiarthritic, } \\
\text { antihistimic, } \\
\text { antieczemic and } \\
\text { anticoronary }\end{array}$ & Rajendran et al. (2017) \\
\hline 8 & 18.34 & 5.49 & .psi.,.psi.Carotene,1,1',2,2'-tetrahydro-1,1'-dimethoxy $\left(\mathrm{C}_{42} \mathrm{H}_{64} \mathrm{O}_{2}\right)$ & $\begin{array}{l}\text { Repellant, } \\
\text { antibacterial, } \\
\text { antifungal, anti- } \\
\text { inflammatory }\end{array}$ & Mebude and Adeniyi (2017) \\
\hline 9 & 18.34 & 5.49 & Lycoxanthin $\left(\mathrm{C}_{40} \mathrm{H}_{56} \mathrm{O}\right)$ & Alcohols, carotenoid & Prasad et al. (2017); Markham ar \\
\hline 11 & 36.13 & 44.82 & 6,9,12,15-Docosatetraenoicacid, methyl ester & $\begin{array}{l}\text { Polyunsaturated } \\
\text { fatty acid, anti- } \\
\text { cholesterol, } \\
\text { anti-carcinogenic } \\
\text { and anti- } \\
\text { atherosclerotic }\end{array}$ & Hussein et al. (2016) \\
\hline 12 & 36.13 & 44.82 & 1-Heptatriacotanol & $\begin{array}{l}\text { Alcoholic compound, } \\
\text { antimicrobial, } \\
\text { anticancer, } \\
\text { nematicide, anti- } \\
\text { inflammatory }\end{array}$ & Anburaj et al. (2016); Jegadeesw \\
\hline
\end{tabular}


Table 6

Chemical composition of the root extract at $100 \mathrm{mg} \mathrm{kg}^{-1}$

\begin{tabular}{|c|c|c|c|c|c|}
\hline $\begin{array}{l}\text { Sl. } \\
\text { No. }\end{array}$ & $\begin{array}{l}\text { RT } \\
\text { (min.) }\end{array}$ & $\begin{array}{l}\text { Area } \\
\%\end{array}$ & Compound name and Molecular formula & Function and Class & References \\
\hline 1 & 5.98 & 12.49 & 2,7-Diphenyl-1,6-dioxopyridazino[4,5:2',3']pyrrolo[4',5'd]pyridazine $\left(\mathrm{C}_{20} \mathrm{H}_{13} \mathrm{~N}_{5} \mathrm{O}_{2}\right)$ & $\begin{array}{l}\text { Alkaloid compound, } \\
\text { antioxidant, anti- } \\
\text { helminthic anti- } \\
\text { inflammatory, anti- } \\
\text { microbial, antimalarial, } \\
\text { antiasthma and anti- } \\
\text { cancerous }\end{array}$ & $\begin{array}{l}\text { Azhagumurugan } \\
\text { and Rajan } \\
\text { (2014); } \\
\text { Altameme et al. } \\
\text { (2015) }\end{array}$ \\
\hline 2 & 5.98 & 12.49 & Gibberellic acid $\left(\mathrm{C}_{19} \mathrm{H}_{22} \mathrm{O}_{6}\right)$ & $\begin{array}{l}\text { Hormone found in } \\
\text { plants, abolishing the } \\
\text { detrimental effects of } \\
\mathrm{Cd} \text { and } \mathrm{Pb}\end{array}$ & $\begin{array}{l}\text { Sharaf et al. } \\
(2009)\end{array}$ \\
\hline 3 & 6.02 & 3.71 & $\begin{array}{l}3[3 \mathrm{Bromophenyl}] 7 \text { chloro3,4dihydro10hydroxy } 1,9(2 \mathrm{H}, 1 \mathrm{HH}) \text { acridinedione }\left(\mathrm{C}_{19} \mathrm{H}_{13}\right. \\
\left.\mathrm{BrClNO}_{3}\right)\end{array}$ & $\begin{array}{l}\text { Alkaloid compound, } \\
\text { Antioxidant, } \\
\text { Hepatostimulant, } \\
\text { hepatocarcinogenic, } \\
\text { herbicide }\end{array}$ & $\begin{array}{l}\text { Jisha et al. } \\
(2016)\end{array}$ \\
\hline 4 & 6.02 & 3.71 & $\begin{array}{l}\text { 3HCyclodeca[b]furan2one,4,9dihydroxy6methyl3,10dimethylene3a,4,7,8,9,10,11,11 } \\
\text { Aoctahydro }\left(\mathrm{C}_{15} \mathrm{H}_{20} \mathrm{O}_{4}\right)\end{array}$ & $\begin{array}{l}\text { Ketone compound, } \\
\text { herbicide, hirudicide, } \\
\text { hormone }\end{array}$ & $\begin{array}{l}\text { Jisha et al. } \\
(2016)\end{array}$ \\
\hline 5 & 6.02 & 3.71 & 90ximino2,7diethoxyfluorene $\left(\mathrm{C}_{17} \mathrm{H}_{17} \mathrm{NO}_{3}\right)$ & Aromatic hydrocarbon & $\begin{array}{l}\text { Chaudhari and } \\
\text { Mahajan (2015) }\end{array}$ \\
\hline 6 & 6.26 & 27.93 & 2-[4-methyl-6-(2,6,6-trimethylcyclohex-1-enyl) hexa-1,3,5-trienyl]cy $\left(\mathrm{C}_{23} \mathrm{H}_{32} \mathrm{O}\right)$ & $\begin{array}{l}\text { Antimicrobials and } \\
\text { anti-viral, found in } \\
\text { plant extracts }\end{array}$ & $\begin{array}{l}\text { Hussein et al. } \\
\text { (2016); Dey et } \\
\text { al. (2016) }\end{array}$ \\
\hline 7 & 6.26 & 27.93 & $\begin{array}{l}\text { 9,12,150ctadecatrienoicacid, } 2[(\text { trimethylsilyl)oxy }] 1[\text { (Trimethyl silyl)oxy]methyl] } \\
\text { ethyl ester, }(\mathrm{Z}, \mathrm{Z}, \mathrm{Z})\left(\mathrm{C}_{27} \mathrm{H}_{52} \mathrm{O}_{4} \mathrm{Si}_{2}\right)\end{array}$ & $\begin{array}{l}\text { Flavonoids, anti- } \\
\text { inflammatory, } \\
\text { antioxidant, } \\
\text { hypocholesterolemic, } \\
\text { cancer preventive, } \\
\text { hepatoprotective, } \\
\text { antiarthritic, } \\
\text { antihistimic, } \\
\text { antieczemic and } \\
\text { anticoronary activity }\end{array}$ & $\begin{array}{l}\text { Rajendran et al. } \\
(2017)\end{array}$ \\
\hline 8 & 6.57 & 6.87 & .psi.,.psi.Carotene,1,1',2,2'tetrahydro1,1' Dimethoxy $\left(\mathrm{C}_{42} \mathrm{H}_{64} \mathrm{O}_{2}\right)$ & $\begin{array}{l}\text { Repellant, antibacterial, } \\
\text { antifungal, anti- } \\
\text { inflammatory }\end{array}$ & $\begin{array}{l}\text { Mebude and } \\
\text { Adeniyi (2017) }\end{array}$ \\
\hline 11 & 7.67 & 17.97 & Astaxanthin $\left(\mathrm{C}_{40} \mathrm{H}_{52} \mathrm{O}_{4}\right)$ & $\begin{array}{l}\text { Keto-carotenoid, } \\
\text { antioxidant activity }\end{array}$ & $\begin{array}{l}\text { Cunningham } \\
\text { and Gantt } \\
\text { (2011); Ambati } \\
\text { et al. (2014) }\end{array}$ \\
\hline 12 & 7.67 & 17.97 & 4Hexyl1(7methoxycarbonylheptyl)bicyclo [4.4.0]deca2,5,7triene $\left(\mathrm{C}_{25} \mathrm{H}_{40} \mathrm{O}_{2}\right)$ & Found in plant extracts & $\begin{array}{l}\text { Karthikeyan et } \\
\text { al. (2016) }\end{array}$ \\
\hline
\end{tabular}

\subsection{Chemotactic effects of root exudates on rhizospheric microorganisms}

The exudates secreted by plants act as a rich source of nutrients for the native microorganisms present in rhizosphere and they participate in early colonization, thereby inducing chemotactic responses of rhizospheric bacteria (Yuan et al. 2015; Sood 2003). The REs from different plant species could alter the physiological properties and type of soil microorganisms (Shi 2004). In this study, after $12 \mathrm{~h}$ of incubation, the microbial growth was found to be inclined towards the REs as compared to DW suggesting chemotactic response of $A$. junii $\mathrm{Pb} 1$, Bacillus subtilis and Bacillus licheniformis, respectively, towards REs and it was visualized by their growth on the petri-dishes (Fig. 7). The composition and concentration of sugars, phenolic acids and flavonoids present in REs from VZ act as an attractant for microorganisms. This result confirms the chemo-attractant property of REs from VZ and thus favours the colonization of microorganisms from the ecological niche. Lei et al. (2017) also reported the positive chemotactic response of Ginseng bacterial soft-rot towards ginseng REs. Bacilio-Jiménez et al. (2003) assessed the chemotactic response of endophytic bacteria towards REs from rice. The authors observed that rice exudates induced high chemotactic response for both Corynebacterium flavescens and Bacillus pumilus. Similarly, Yuan et al. (2015) reported that banana exudates induced chemotaxis and biofilm formation in plant growth promoting rhizobacteria strain Bacillus amyloliquefaciens NJN-6. Thus, evidently, the chemical compounds present in REs of VZ served as a chemoattractant for these bacterial cultures. The chemotaxis between REs and bacteria act as one of the several mode of interaction between bacteria and the plant. Anew, it was demonstrated that the root exudates play an important role for the survival of plants under abiotic stress and also in initiating and enticing PGPR colonization on the host roots. From a practical knowledge perspective, further research is required to analyse the components of REs and their contribution using sophisticated techniques such as UPLC-Q-TOF or NMR and ascertain their role in HM bioremediation by performing (bio)leaching experiments and pot soil culture experiments. 


\section{Conclusions}

The results from photochemical tests show that VZ REs and REt contains various bioactive phyto-constituents such as carbohydrate, protein, phenolic, flavonoid and alkaloid. When treated with $\mathrm{Pb}(\mathrm{II})$, the presence of phyto-constituents in REs and REt improved the defence mechanism and enhanced heavy metal stress tolerance. The chemotactic response of rhizospheric bacterial strains towards VZ exudates demonstrated the crucial role in attracting and initiating colonization on the host roots. A dual role in the production of secondary metabolites with imperative biological properties appears to have good practical implications in the field of bioremediation.

\section{Declarations}

\section{Ethics approval:}

The article does not contain any studies performed on animals; Approval from "Institute Ethical Committee" not required.

\section{Consent to participate:}

Not Applicable

\section{Consent for publication:}

Not Applicable

\section{Availability of data:}

All the experimental data of the study is included in this article, some of it has been provided as supplementary files.

\section{Competing interests:}

The authors AK, NH, BSG, ER, RR declare no competing interests.

\section{Funding:}

Study was funded by DST-SERB via project no. ECR/2017/001175

\section{Authors contribution:}

AK, RR conceived and planned the study; AK, NH, RR performed the experiments; AK, RR, BSG, ER performed data interpretation; AK,RR,BSG,ER wrote and refined the manuscript

\section{References}

1. Abdul-Hafeez, E.Y., Mahmoud, A.F., Ibrahim, O.H.M. (2015). Antibacterial activities and phytochemical screening of Alhagi pseudalhagi. Assiut J. Agric. Sci. 46:33-47.

2. Abubacker, M.N., Devi, P.K., (2015). In vitro antifungal potentials of bioactive compounds heptadecane, 9-hexyl and ethyl iso-allocholate isolated from Lepidagathis cristata (Acanthaceae) leaf. British Biomed. Bullet. 3:336-343.

3. Ali, H., Khan, E., Sajad, M.A. (2013). Phytoremediation of heavy metals - concepts and applications. Chemosphere. 91:869-881.

4. Altameme, H.J., Hameed, I.H., Kareem, M.A. (2015). Analysis of alkaloid phytochemical compounds in the ethanolic extract of Datura stramonium and evaluation of antimicrobial activity. Afr. J. Biotechnol. 14:1668-1674.

5. Ambati, R.R., Phang, S.M., Ravi, S., Aswathanarayana, R.G. (2014). Astaxanthin: sources, extraction, stability, biological activities and its commercial applications - a review. Mar. Drugs. 12:128-152.

6. Anburaj, G., Marimuthu, M., Raja Sudha, V., Manikandan, R., (2016). Phytochemical screening and GC-MS analysis of ethanolic extract of Tecoma stans (Family: Bignoniaceae) Yellow Bell Flowers. J. Pharmacogn Phytochem. 5:172.

7. ArefiFard, M. (2017). The Study of the Effect of Nickel Heavy Metal on Some Growth Parameters and Production of Alkaloids in Catharanthus roseus. In: Catharanthus roseus Springer, Cham. pp. 399-412.

8. Arora, D.K. ed., (1991). Handbook of Applied Mycology: Volume 1: Soil and Plants. CRC Press.

9. Arul Manikandan, N, Alemu AK, Goswami L, Pakshirajan K, Pugazhenthi G. (2016). Waste litchi peels for Cr (VI) removal from synthetic wastewater in batch and continuous systems: sorbent characterization, regeneration and reuse study. J. Environ. Eng. 142: C4016001.

10. Azhagumurugan, C., Rajan, M.K., (2014). GC-MS Analysis of Methanalic Leaf Extract of Nilakkumil, Gmelina asiatica. Afr. J. Basic Appl. Sci. 6:153-158. 
11. Baba, S.A., Malik, S.A., (2015). Determination of total phenolic and flavonoid content, antimicrobial and antioxidant activity of a root extract of Arisaema jacquemontii Blume. J. Taibah Univ. Sci. 9:449-454.

12. Bacilio-Jiménez, M., Aguilar-Flores, S., Ventura-Zapata, E., Pérez-Campos, E., Bouquelet, S., Zenteno, E., (2003) Chemical characterization of root exudates from rice (Oryza sativa) and their effects on the chemotactic response of endophytic bacteria. Plant Soil. 249:271-277.

13. Bautista-Lozada, A. Espinosa-García, F.J., (2013). Odor uniformity among tomato individuals in response to herbivore depends on insect species. PloS One. 8: 77199.

14. Bind A, Goswami L, Prakash V., (2018). Comparative analysis of floating and submerged macrophytes for heavy metal (copper, chromium, arsenic and lead) removal: sorbent preparation, characterization, regeneration and cost estimation. Geology, Ecology, and Landscapes. 2:61-72.

15. Bind, A., Kushwaha, A., Devi, G., Goswami, S., Sen, B., Prakash, V. (2019). Biosorption valorization of floating and submerged macrophytes for heavy-metal removal in a multi-component system. Applied Water Science, 9(4):95.

16. Bradford, M.M., (1976). A rapid and sensitive method for the quantitation of microgram quantities of protein utilizing the principle of protein-dye binding. Anal. Biochem. 72: 248-254.

17. Chang, C.C., Yang, M.H., Wen, H.M., Chern, J.C., (2002). Estimation of total flavonoid content in propolis by two complementary colorimetric methods. J. Food Drug Anal. 10:178-182.

18. Chaudhari, G.M., Mahajan, R.T., (2015). Comprehensive study on pharmacognostic, physico and phytochemical evaluation of Terminalia arjuna Roxb. stem bark. J. Pharmacogn. Phytochem. 4:186.

19. Choi, H.W., Lee, B.G., Kim, N.H., Park, Y., Lim, C.W., Song, H.K., Hwang, B.K., (2008). A role for a menthone reductase in resistance against microbial pathogens in plants. Plant Physiol. 148: 383-401.

20. Cunningham, F.X., Gantt, E., (2011). Elucidation of the pathway to astaxanthin in the flowers of Adonis aestivalis. The Plant Cell: 111.

21. Dey, P., Dutta, S., Chaudhuri, T.K., (2015). Comparative phytochemical profiling of Clerodendrum infortunatum L using GC-MS method coupled with multivariate statistical approaches. Metabolomics. 5:2153-0769.

22. Dilika, F., Bremner, P.D., Meyer, J.J.M., (2000). Antibacterial activity of linoleic and oleic acids isolated from Helichrysum pedunculatum: a plant used during circumcision rites. Fitoterapia, 71: 450-452.

23. Dutta, M., Kushwaha, A., Kalita, S., Devi, G., \& Bhuyan, M. (2019). Assessment of bioaccumulation and detoxification of cadmium in soil-plant-insect food chain. Bioresource Technology Reports, 7:100242.

24. Fan, T.W.M., Lane, A.N., Shenker, M., Bartley, J.P., Crowley, D., Higashi, R.M., (2001). Comprehensive chemical profiling of gramineous plant root exudates using high-resolution NMR and MS. Phytochemistry. 57: 209-221.

25. Gaidamak, V.M., (1971). Biologically active substances in nutrient solutions after cucumbers and tomatoes were grown on pure and multiple used broken brick. (Ed.: A.M. Grodzinsky) Physiological biochemical basis of plant interactions in phytocenosis Vol 2. Kiev: Naukova Dumka, pp. 55-60.

26. Gohari, M., Habib-Zadeh, A.R., Khayat, M., (2012). Assessing the intensity of tolerance to lead and its effect on amount of protein and proline in root and aerial parts of two varieties of rape seed (Brassica napus L.). J. Basic Appl. Sci. Res. 2: 935-938.

27. Goswami, L., Manikandan, N.A., Pakshirajan, K., Pugazhenthi, G., (2017). Simultaneous heavy metal removal and anthracene biodegradation by the oleaginous bacteria Rhodococcus opacus. Biotech. 7:37.

28. Goswami, L., Pakshirajan, K., \& Pugazhenthi, G. (2020). Biological treatment of biomass gasification wastewater using hydrocarbonoclastic bacterium Rhodococcus opacus in an up-flow packed bed bioreactor with a novel waste-derived nano-biochar based bio-support material. Journal of Cleaner Production, 256:120253.

29. Hedge, I.E., Hofreiter, B.T., (1962). Carbohydrate Chemistry i7 (Eds. Whistler R.L., Be Miller, J.N) Academic Press New York.

30. Huang, X.X., Bie, Z.L., Huang, Y., (2010). Identification of autotoxins in rhizosphere soils under the continuous cropping of cowpea. Allelopathy J. 25: 383392.

31. Hussein, H.J., Hadi, M.Y., Hameed, I.H., (2016). Study of chemical composition of Foeniculum vulgare using Fourier transform infrared spectrophotometer and gas chromatography-mass spectrometry. J. Pharmacognosy Phytother. 8:60-89.

32. Irtelli, B., Navari-Izzo, F., (2006). Influence of sodium nitrilotriacetate (NTA) and citric acid on phenolic and organic acids in Brassica juncea grown in excess of cadmium. Chemosphere. 65:1348-1354.

33. Jegadeeswari, P., Nishanthini, A., Muthukumarasamy, S., Mohan, V.R., (2012). GC-MS analysis of bioactive components of Aristolochia krysagathra (Aristolochiaceae). J. Curr. Chem. Pharm. Sci. 2: 226-232.

34. Jha, P., Panwar, J., Jha, P.N., (2015). Secondary plant metabolites and root exudates: guiding tools for polychlorinated biphenyl biodegradation. Int. J. Environ. Sci. Technol. 12: 789-802.

35. Jiménez-Osornio, F.J., Kumamoto, J., Wasser, C., (1996). Allelopathic activity of Chenopodium ambrosioides L. Biochem. Syst. Ecol. 24: 195-205.

36. Jisha M., Zeinul Hukuman N.H., Leena P., (2016). GC-MS analysis of leaves and flowers of Pogostemon Quadrifolius (benth.) F. muell. (lamiaceae). World J. Pharm. Res. 5:667-681.

37. Jung, C., Maeder, V., Funk, F., Frey, B., Sticher, H., Frossard, E., (2003). Release of phenols from Lupinus albus L. roots exposed to Cu and their possible role in Cu detoxification. Plant Soil. 252: 301-312.

38. Kadhim, M.J., Mohammed, G.J., Hameed, I.H., (2016). In Vitro Antibacterial, Antifungal and Phytochemical Analysis of Methanolic Extract of Fruit Cassia Fistula. Orient. J. Chem. 32: 1329-1346. 
39. Karthikeyan, K., Abitha, S., Kumar, V.S., (2016). Identification of Bioactive Constituents in Peel, Pulp of Prickly Custard Apple (Annona muricata) and its Antimicrobial Activity. Int. J. Pharm. Phytochem. Res. 8:1833-1838.

40. Kaur, C., Kapoor, H.C., (2002). Anti-oxidant activity and total phenolic content of some Asian vegetables. Int. J. Food Sci. Technol. 37:153-161.

41. Keeling, C.I., BohImann, J., (2006). Genes, enzymes and chemicals of terpenoid diversity in the constitutive and induced defence of conifers against insects and pathogens. New Phytol. 170: 657-675.

42. Khaleel, C., Tabanca, N., Buchbauer, G., (2018). a-Terpineol, a natural monoterpene: A review of its biological properties. Open Chem. 16: $349-361$.

43. Kim, S., Lim, H., Lee, I., (2010). Enhanced heavy metal phytoextraction by Echinochloa crus-galli using root exudates. J. Biosci. Bioeng. 109, 47-50.

44. Kishimoto, K., Matsui, K., Ozawa, R., Takabayashi, J., (2005). Volatile C6-aldehydes and allo-ocimene activate defense genes and induce resistance against Botrytis cinerea in Arabidopsis thaliana. Plant Cell Physiol. 46(7): pp.1093-1102.

45. Kishimoto, K., Matsui, K., Ozawa, R., Takabayashi, J., (2006). Analysis of defensive responses activated by volatile allo-ocimene treatment in Arabidopsis thaliana. Phytochemistry, 67: 1520-1529.

46. Krishnaraj, C., Jagan, E.G., Ramachandran, R., Abirami, S.M., Mohan, N., Kalaichelvan, P.T., (2012). Effect of biologically synthesized silver nanoparticles on Bacopa monnieri (Linn.) Wettst. plant growth metabolism. Process Biochem. 47: 651-658.

47. Kumar, S., Pandey, A.K., (2013). Chemistry and biological activities of flavonoids: an overview. Scientific World J., 2013 : Article ID 162750.

48. Kushwaha A, Rani R, Kumar S, Gautam A., (2015). Heavy metal detoxification and tolerance mechanisms in plants: Implications for phytoremediation. Environ. Rev. 23: 1-13.

49. Kushwaha A, Rani R, Kumar S., (2017). Mechanism of Soil-Metal-Microbe Interactions and their Implication on Microbial Bioremediation and Phytoremediation. In: Environmental Science and Engineering, Biodegradation and Bioremediation, $1^{\text {st }}$ Ed., Volume 8, Eds. Kumar, P., Gurjar, B.R., Govil, J.N., Studium Press LLC, U.S.A.

50. Kushwaha, A., Rani, R., and Patra, J. K. (2020). Adsorption kinetics and molecular interactions of lead [Pb (II)] with natural clay and humic acid. Int. J. Environ. Sci. Tec., 1-12.

51. Lei, F., Fu, J., Zhou, R., Wang, D., Zhang, A., Ma, W., Zhang, L., (2017). Chemotactic response of Ginseng bacterial soft-rot to Ginseng root exudates. Saudi J. Biol. Sci., 24(7): 1620-1625.

52. Liebersbach, H., Steingrobe, B., Claassen, N., (2004). Roots regulate ion transport in the rhizosphere to counteract reduced mobility in dry soil. Plant Soil. 260:79-88.

53. Lim, T.K., (2016). Edible Medicinal and Non-Medicinal Plants: Volume 12, Modified Stems, Roots, Bulbs. Springer, Dordrecht, Netherland, pp. $308-353$.

54. Luo, Q., Sun, L., Hu, X., Zhou, R., (2014). The variation of root exudates from the hyperaccumulator Sedum alfredii under cadmium stress: metabonomics analysis. PloS One, 9(12): p.e115581.

55. Luo, Q., Sun, L.N., Wang, H., Hu, X.M., (2015). Metabolic profiling analysis of root exudates from the Cd hyperaccumulator Sedum alfredii under different Cd exposure concentrations and times. Anal. Methods. 7: 3793-3800.

56. Markham, M.C., Liaaen-Jensen, S., (1968). Carotenoids of higher plants-I the structures of lycoxanthin and lycophyll. Phytochemistry, 7: $839-844$.

57. Márquez-García, B., Fernández-Recamales, M., Córdoba, F., (2012). Effects of cadmium on phenolic composition and antioxidant activities of Erica andevalensis. (2012), Article ID 936950.

58. Mebude, O.O., Adeniyi, B., (2017). GC-MS Analysis of Phyto components from the stem bark of Cola nitida Schott \& Endl. J. Plant Sci. 5: $99-103$.

59. Miller, G. L., (1959). Use of dinitro salicylic acid reagent for determination of reducing sugar. Anal. Chem. 31: 426-428.

60. Mneimne, M., Baydoun, S., Nemer, N., Arnold, A.N., (2016). Chemical composition and antimicrobial activity of essential oils isolated from aerial parts of Prangos Asperula Boiss. (Apiaceae) growing wild in Lebanon. Med. Plant Res., 5(3):1000242.

61. Mohammed, G.J., Omran, A.M., Hussein, H.M., (2016). Antibacterial and phytochemical analysis of Piper nigrum using gas chromatography-mass spectrum and Fourier-transform infrared spectroscopy. Int. J. Pharmacogn. Phytochem. Res. 8: 977-996.

62. Morah, I., Frank, N., Uduagwu, D.N., (2017). Chemical composition, antioxidant and larvicidal activity of Alchornea laxiflora (Benth) leaf extracts. Edorium J. Dent. 1: 1-8.

63. Musilova, L., Ridl, J., Polivkova, M., Macek, T., Uhlik, O., (2016). Effects of secondary plant metabolites on microbial populations: Changes in community structure and metabolic activity in contaminated environments. Int. J. Mol. Sci. 17: 1205.

64. Najafian, S., Zahedifar, M., (2015). Antioxidant activity and essential oil composition of Satureja hortensis L. as influenced by sulfur fertilizer. J. Sci. Food Agric. 95: 2404-2408.

65. Omoruyi, B.E., Muchenje, V., (2017). Phyto medical assessment of two Cymbopogon species found in Nkonkobe Municipality: Toxicological effect on human Chang liver cell line. BMC Complementary Altern. Med. 17: 287.

66. Parry, A. D., Tiller, S. A., Edwards, R., (1994). The effects of heavy metals and root immersion on isoflavonoid metabolism in alfalfa (Medicago sativa L.). Plant Physiol.106: 195-202.

67. Pilon-Smits, E., (2005). Phytoremediation. Annu. Rev. Plant Biol. 56: 15-39.

68. Prasad, K., Bansal, V., Siddiqui, M.W., (2017). Plant Secondary Metabolites, Volume 2 Stimulation, Extraction, and Utilization. Apple Academic Press, CRC Press.

69. Radmanesh, E., Naghdi Badi, H., Hadavi, E., Mehrafarin, A., (2015). Shoot growth, gamma-terpinene and essential oil content of Satureja hortensis L. in response to foliar application of $\mathrm{FeSO}_{4}$ and citric acid. J. Med. Plant. 14:45-57. 
70. Raj, A.A.S., Aaron, S., (2014). Review on-recent trends in isolation of antioxidants from spices and its biological effects of essential oils. Int. J. Eng. Res. Appl. 4: 75-84.

71. Rajendran, P., Bharathidasan, R., Suresh Kumar, K., (2017). GC-MS Analysis of Phyto-components in raw and treated sugarcane juice. Int. J. Curr. Microbiol. App. Sci. 6: 51-61.

72. Rajkumar, M., Sandhya, S., Prasad, M.N.V., Freitas, H., (2012). Perspectives of plant-associated microbes in heavy metal phytoremediation. Biotechnol. Adv. 30: 1562-1574.

73. Rani, R. and Juwarkar, A., (2015), May. Effect of presence of pesticides in growth medium on the exudation behaviour of plants: a study with phorate (an organophosphate insecticide) and Pisun sativum (L.). In: Proceedings of the International Conference on Biological, Environment and Food Engineering (BEFE-2015).

74. Rani, R., Juwarkar, A., (2016). Influence of insecticide phorate on chemical composition and enzyme profile of root exudates and root extracts of Brassica juncea. J. Environ. Biol. 37: 413-419.

75. Rascio, N., Navari-Izzo, F., (2011). Heavy metal hyperaccumulating plants: how and why do they do it? And what makes them so interesting? Plant science, 180: 169-181.

76. Ruberto, G., Baratta, M.T., (2000). Antioxidant activity of selected essential oil components in two lipid model systems. Food Chem. 69: 167-174.

77. Runde M., Kubmarawa D., Maina H., (2015). Compositional analysis and antimycobacterium tuberculosis activity of essential oil of Hyptis Suaveolens Lamiceae. Res. J. Chem. Sci. 5: 40-44.

78. Sathe, S.S., Goswami, L., Mahanta, C., Devi, L.M. (2020). Integrated factors controlling arsenic mobilization in an alluvial floodplain. Environmental Technology \& Innovation, 17: 100525.

79. Shah, K., Mankad, A.U., Reddy, M.N., (2017). Cadmium accumulation and its effects on growth and biochemical parameters in Tagetes erecta L. J. Pharmacogn. Phytochem. 6: 111-115.

80. Sharaf, A.E.M.M., Farghal, I.I., Sofy, M.R., (2009). Role of gibberellic acid in abolishing the detrimental effects of Cd and Pb on broad bean and Lupin plants. Res. J. Agric. Biol. Sci, 5: 668-673.

81. Shaw, L.J., Burns, R.G., (2004). Enhanced mineralization of [U-14C] 2,4-dichlorophenoxyacetic acid in soil from the rhizosphere of Trifolium pratense. Appl. Environ. Microbiol. 70: 4766-4774.

82. Shi, G., (2004). Ecological effects of plant root exudates. Chinese J. Ecol. 23: 97-101.

83. Silva, W.R., Machado, A.R., Campos, V.A., Zeri, A., Campos, V.P., Oliveira, D.F., (2013). Volatile organic compounds for the control of Meloidogyne exigua in Coffea arabica. Trop. Plant. Pathol. 38: 375-386.

84. Singh, P.K., Kushwaha, A., Hans, N., Gautam, A. and Rani, R., (2019). Evaluation of the cytotoxicity and interaction of lead with lead resistant bacterium Acinetobacter junii Pb1. Braz. J. Microbiol., 50: 223-230.

85. Sinha, R. K., Valani, D., Sinha, S., Singh, S., Herat, S. (2009). Bioremediation of contaminated sites: a low-cost nature's biotechnology for environmental clean-up by versatile microbes, plants \& earthworms. In: Solid Waste Management and Environmental Remediation, Eds. Faerber, T., Herzog, J., Nova Publishers: pp. 1-72.

86. Sood, S.G, (2003). Chemotactic response of plant-growth-promoting bacteria towards roots of vesicular-arbuscular mycorrhizal tomato plants. FEMS Microbiol. Ecol. 45: 219-227.

87. Srivastava, N.K., Srivastava, A.K., (2010). Influence of some heavy metals on growth, alkaloid content and composition in Catharanthus roseus L. Indian J. Pharm. Sci. 72: 775.

88. Srivastava, R., Mukherjee, A., Verma, A., (2015). GC-MS Analysis of phytocomponents in Pet ether fraction of Wrightia tinctoria seed. Pharmacogn. J. 7(4):249-253.

89. Sundar, S., Justin K.P.Y., (2015). Phytochemical screening and gas chromatograph-mass spectrometer profiling in the leaves of Solanum Incanum L. Asian J. Pharm. Clin. Res. 8.

90. Tambe, V.D., Bhambar, R.S., (2014). Estimation of total phenol, tannin, alkaloid and flavonoid in Hibiscus tiliaceus Linn. wood extracts. Research and reviews: J. Pharmacogn. Phytochem. 2: 41-47.

91. Tang, Y.L., Deng, Y.R., Wang, H.Q., (2003). Chemical components of essential oils from the herb of Ligularia virgaurea. Zhongguo Zhong Yao Za Zhi., 28(7): 627-629.

92. Tayade, A.B., Dhar, P., Kumar, J., Sharma, M., Chauhan, R.S., Chaurasia, O.P., Srivastava, R.B., 2013. Chemometric profile of root extracts of Rhodiola imbricata Edgew with hyphenated gas chromatography mass spectrometric technique. PLoS One, 8(1): p.e52797.

93. Tripathi, A.K., Mishra, S., (2016). Plant Monoterpenoids (Prospective Pesticides). In Eco-friendly Pest Management for Food Security, 507-524.

94. Tuemova, L., Ruskova, R., (1998). Effects of $\mathrm{CdCl}_{2}$ and $\mathrm{CuSO}_{4}$ on the production of flavonoids by the culture of Ononis arvensis $\mathrm{L}$. in vitro. Ceska A Slovenska Farmacie, 261-263.

95. Turner, J.G., Ellis, C., Devoto, A., (2002). The jasmonate signal pathway. Plant Cell. 14: S153-S164.

96. Upchurch, R.G., (2008). Fatty acid unsaturation, mobilization, and regulation in the response of plants to stress. Biotechnol. Lett. 30 : $967-977$.

97. Usharani, B., Vasudevan, N., (2017). Root exudates of Cyperus alternifolius in partial hydroponic condition under heavy metal stress. Pharmacogn. Res. 9: 294-300.

98. Venkatachalam, P., Jayalakshmi, N., Geetha, N., Sahi, S.V., Sharma, N.C., Rene, E.R., Sarkar, S.K., Favas, P.J., (2017). Accumulation efficiency, genotoxicity and antioxidant defense mechanisms in medicinal plant Acalypha indica L. under lead stress. Chemosphere, 171: 544-553. 
99. Wadhwa, K., Narula, N., (2012). A novel technique to collect root exudates from mustard (Brassica juncea). J. Basic Microbiol. 52: 613-615. 100. Wang, P., Bi, S., Wang, S., Ding, Q., (2006). Variation of wheat root exudates under aluminium stress. J. Agric. Food Chem. 54: 10040-10046.

101. Yuan, J., Zhang, N., Huang, Q., Raza, W., Li, R., Vivanco, J.M., Shen, Q., (2015). Organic acids from root exudates of banana help root colonization of PGPR strain Bacillus amyloliquefaciens NJN-6. Sci. Rep. 5: 13438.

\section{Figures}

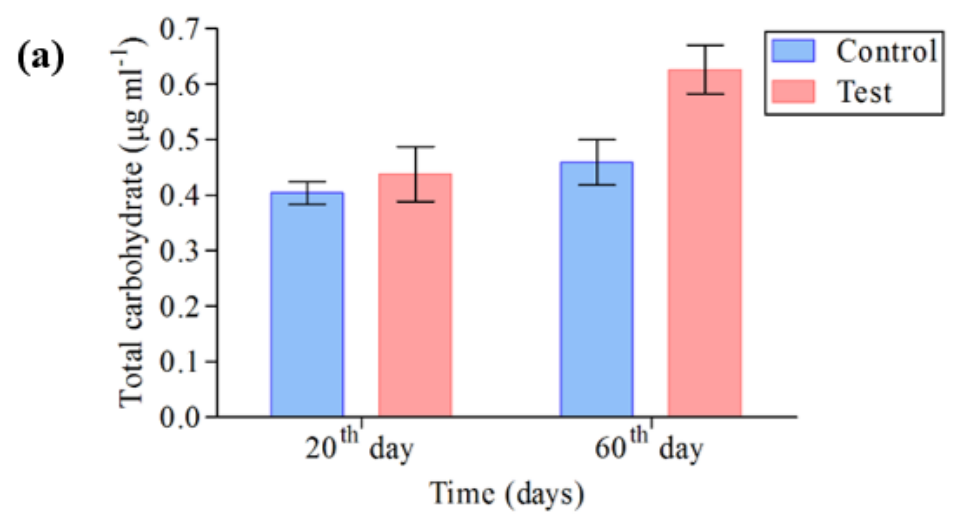

(b)

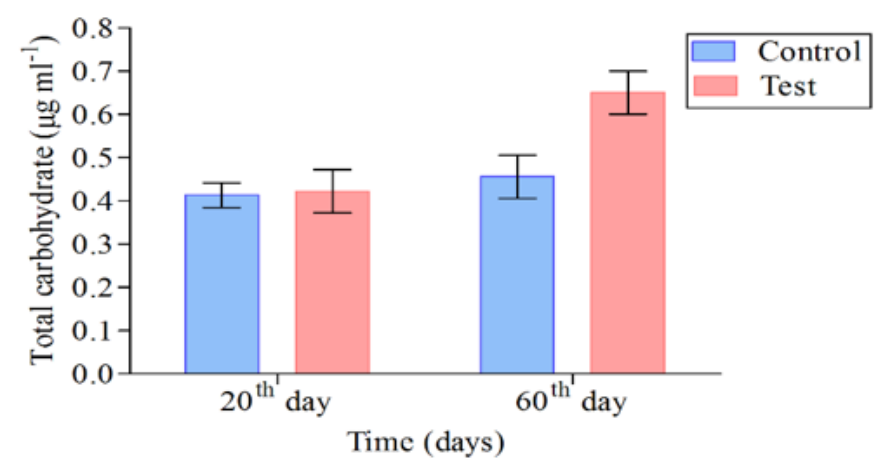

Figure 1

Total carbohydrate content: (a) root exudates, and (b) root extract 
(a)

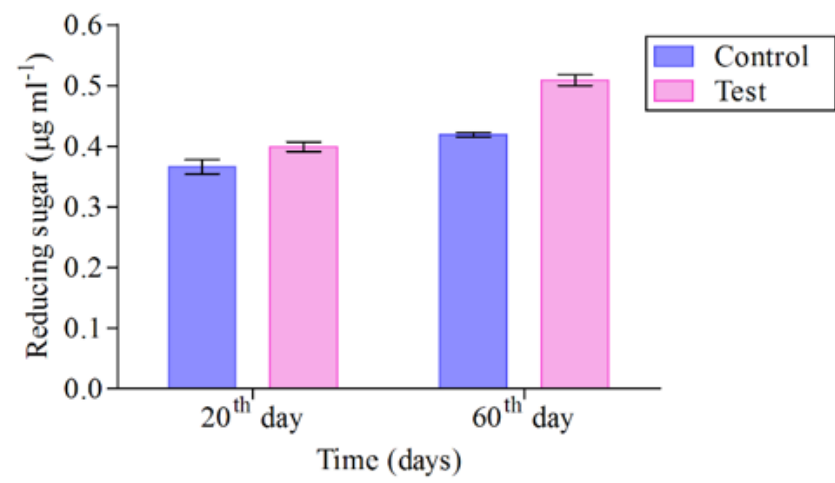

(b)

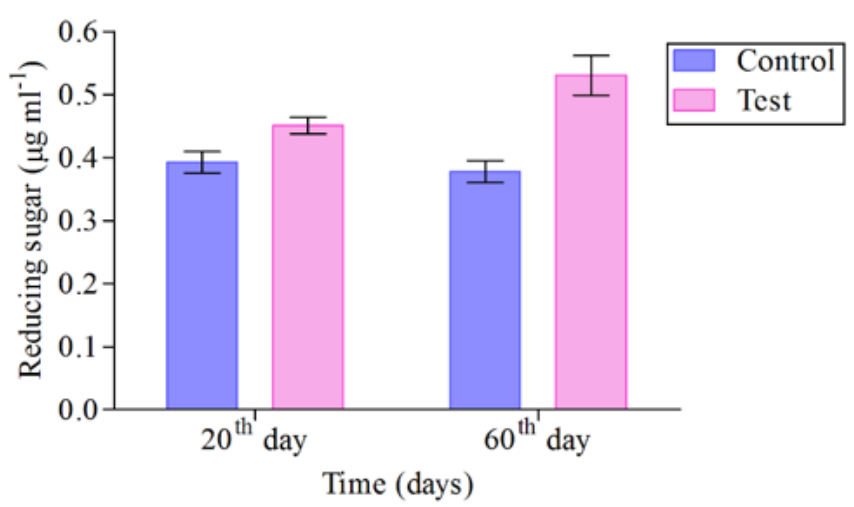

Figure 2

Reducing sugar content: (a) root exudates, and (b) root extract

(a)

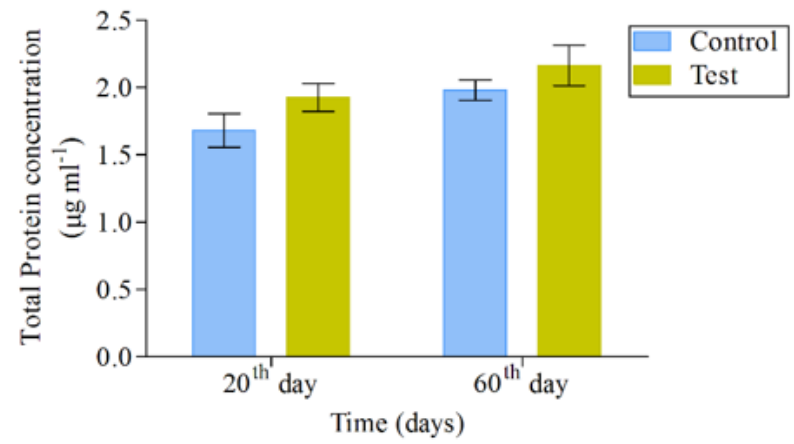

(b)

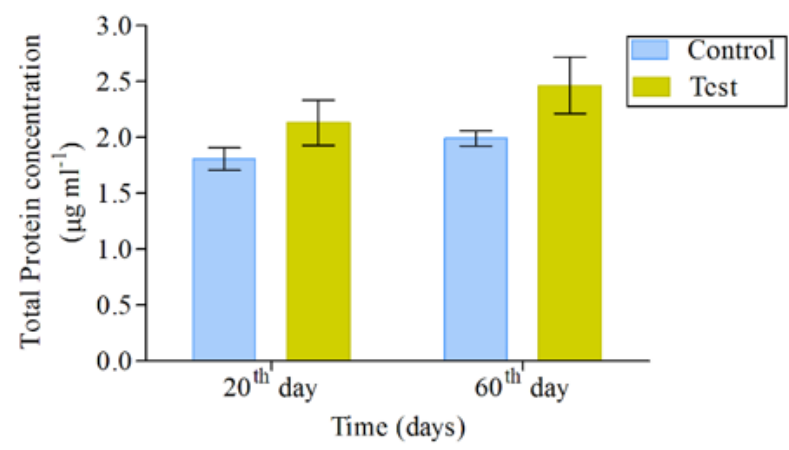

Figure 3

Total protein estimation: (a) root exudates, and (b) root extract 
(a)

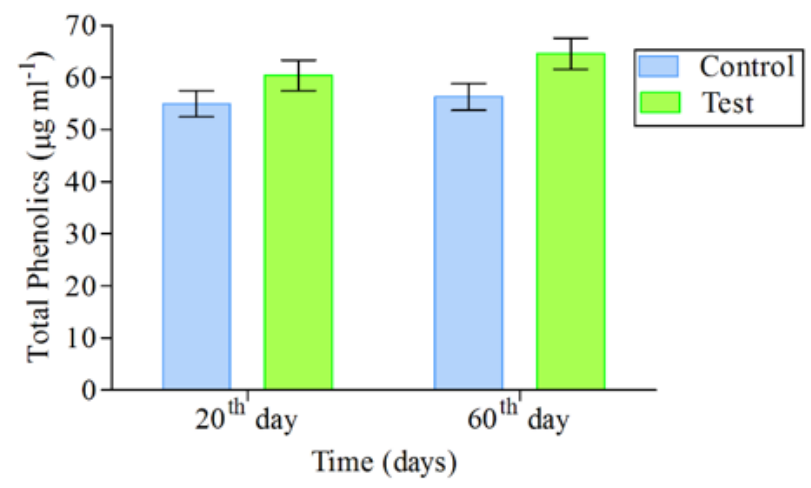

(b)

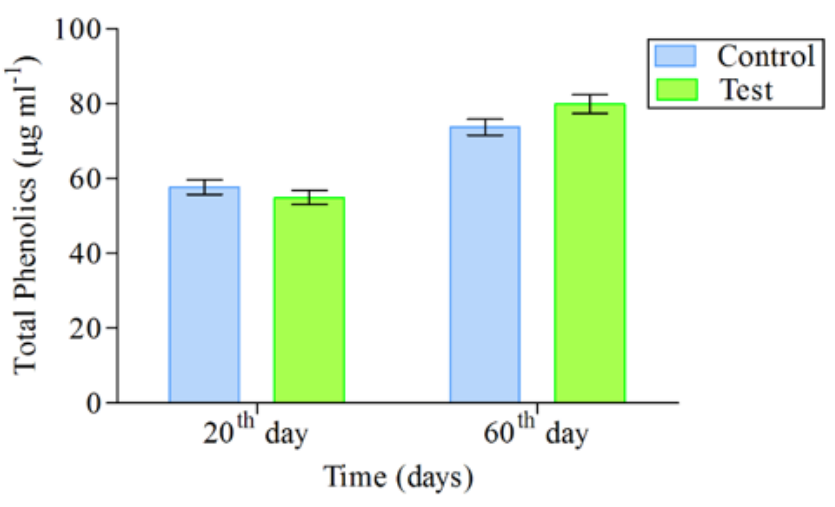

Figure 4

Total phenolic content: (a) root exudates, and (b) root extract

(a)

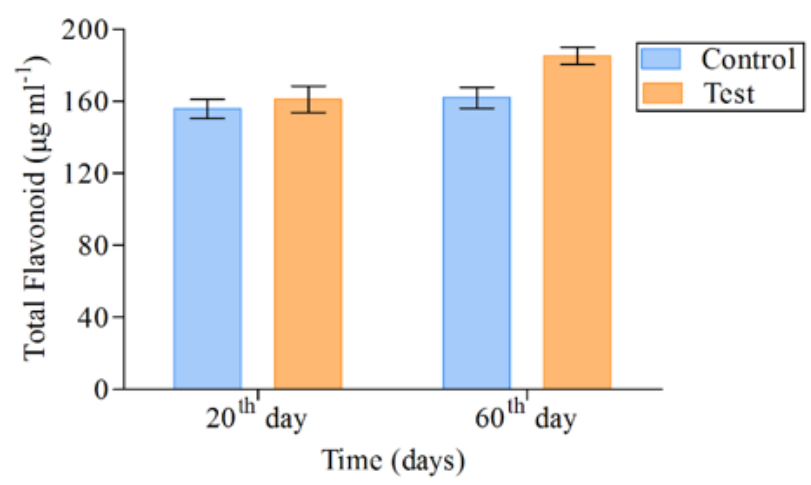

(b)

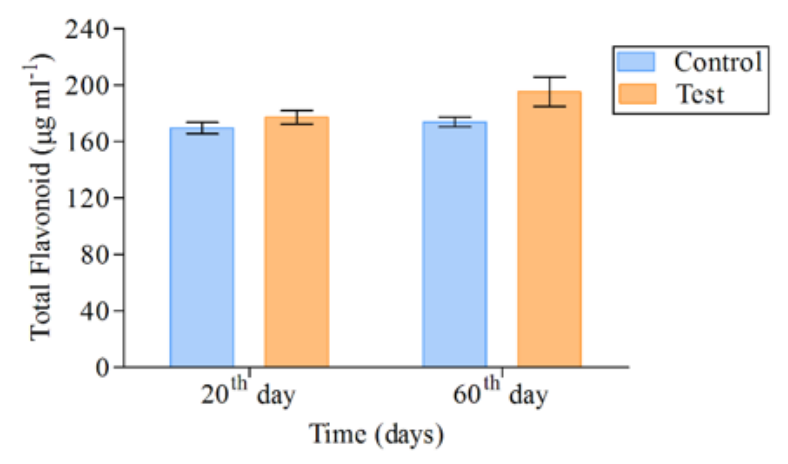

Figure 5

Total flavonoids content: (a) root exudates, and (b) root extract 
(a)

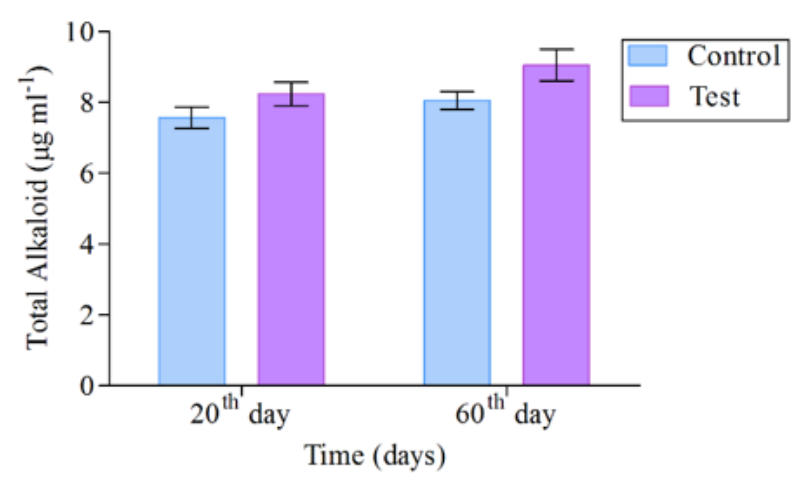

(b)

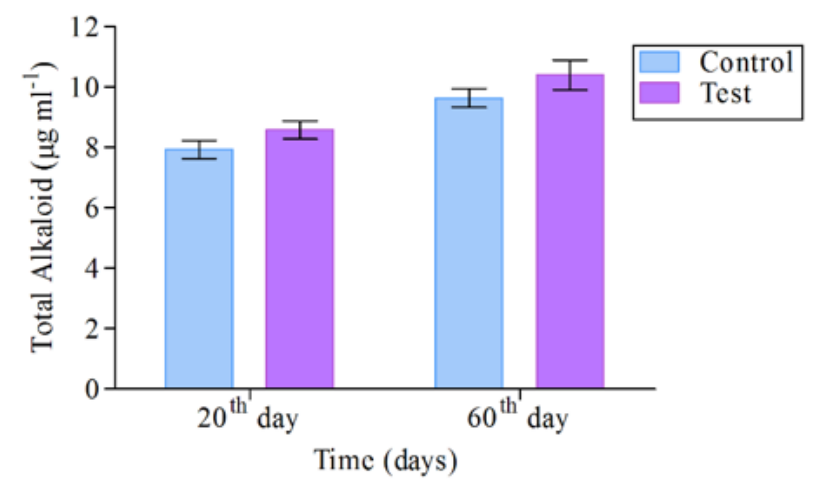

\section{Figure 6}

Total alkaloid content: (a) root exudates, and (b) root extract

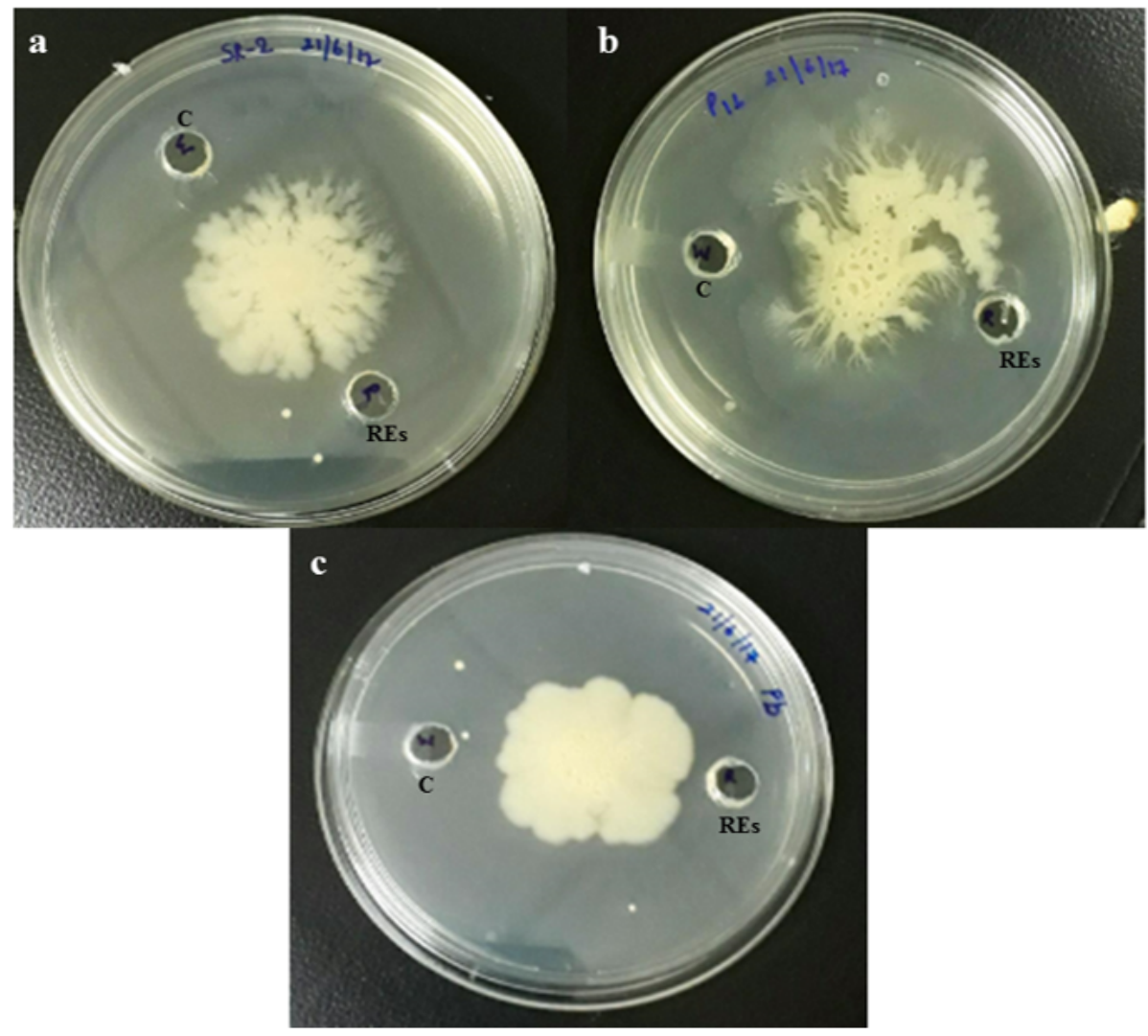

\section{Figure 7}

Chemotactic effect of REs on bacterial isolates: (a) Bacillus subtilis, (b) Bacillus licheniformis and (c) A. junii Pb1 (C: control and REs: root exudates) 


\section{Supplementary Files}

This is a list of supplementary files associated with this preprint. Click to download.

- SupplementaryInfo.docx 